\title{
Rehabilitation of Damaged Reinforced Concrete Beams
}

\author{
Wail Nourildean Al-Rifaie, Ph.D ${ }^{1}$, Nezar N. Ismaeel, Ph.D ${ }^{2}$ and \\ Hamza Riyad, M.Sc ${ }^{3}$ \\ ${ }^{1}$ Professor of Civil Engineering, Philadelphia University, Amman, Jordan. \\ ${ }^{2}$ Lecturer, College of Engineering, University of Tikrit, Iraq. \\ ${ }^{3}$ Research Scholar, College of Engineering, University of Tikrit, Iraq.
}

\begin{abstract}
The concrete structures are often exposed to damaged as a result of several factors including, environment, design, and other factors, and because of the high cost and long time needed for reconstruction of the damaged buildings, it become necessary to consider techniques for rehabilitation of the damaged structural members in the building.

12 reinforced concrete beams $(2200 \times 200 \times 150 \mathrm{~mm})$ were cast and tested under point load at mid-span to limit the failure. Several techniques for repairing the damaged beams are carried out in the present work. Ferrocement composite, steel plate, fiber carbon reinforced polymer (FCRP), nano cement composite, and the injection of the developed nano cement mortar are considered.
\end{abstract}

Keywords: Rehabilitation; Nano; Micro; failure load.

\section{Introduction}

Exposed concrete structures to damage, as a result of some natural disasters such as earthquakes or hurricanes, or as a result of exposure to abnormal loads, or something wrong in the design, or a bug in the implementation or a decrease in the area of reinforcement as a result of rust and corrosion with the passage of time, or a change in function and increased loads of service to its members, which did not intervene during the initial design and thus carries origin stresses more than afford it.

In 2010 Bhikshma and et.al ${ }^{(1)}$, presented an investigation to determine the suitability of epoxy resin material type to be used in reinforced concrete beams for repairing and restoring good strength. In their work six beams $(150 \times 230 \times 1500 \mathrm{~mm})$ for M50 grade of concrete were distressed in flexure due to the application of two point loads by taking $90 \%$ of the ultimate load. The distressed beams were then repaired and retested up to ultimate failure load. Three types of epoxy resin materials were considered for repairing. The results of these experiments show that the beams repaired using epoxy resin material (EXPACRETE SNE1) gave higher increase in the ultimate load than other epoxy resin materials. Sivagurunathan and Vidivelli in $2012^{(2)}$ proposed the application of ferrocement layer for strengthening the predamaged reinforced concrete beams. Eight beams of size $125 \times 250 \times 3200 \mathrm{~mm}$ were cast and tested for flexure. Six of these beams were loaded to a predetermined damaged level, and strengthened by fastening ferrocement laminates using epoxy resin adhesive and then tested again by conducting flexural test for ultimate load carrying capacity. They concluded that ferrocement can be used as strengthening materials for reinforced concrete beams damaged due to overloading.

The present work associated with the behaviour of rehabilitation the damaged reinforced concrete beams by using several techniques. 12 reinforced concrete beams of size $120 \mathrm{~mm}$ width, $200 \mathrm{~mm}$ depth and $2200 \mathrm{~mm}$ overall length were cast and tested for flexure. The damaged beams were loaded to a failure and then repaired by several teckniques. The repaired beams were again tested for ultimate load carrying capacity by conducting the same flexural test. A comparative study was made between the failure behaviour before and after repairing.

\section{Testing procedure}

\section{Experimental Program}

1. 12 reinforced concrete $150 \times 200 \times 2200 \mathrm{~mm}$ beams were constructed. Beams were design to avoid shear failure, in which the beams were reinforced by four bars (12 $\mathrm{mm}$ diam.), 2-bars at the top and 2-bars at the bottom of the cross section with $10 \mathrm{~mm}$. diam. at $250 \mathrm{~mm}$ c/c stirrups.

2. The beams were loaded until failure and first crack and ultimate loads were recorded.

3. Rehabilitate the damaged beams with several method of repairing.

Materials used in the present work

Cement: Ordinary Portland cement were used throughout the present investigation for casting the reinforced concrete. The chemical composition and physical properties are tabulated in Tables (1) and (2). 
Table (1): Chemical composition of the Ordinary Portland cement used during the present investigation.

\begin{tabular}{|c|c|c|}
\hline Compound composition & Chemical compositio & Weight (\%) \\
\hline Lime & $\mathrm{CaO}$ & 62.28 \\
\hline Silica & $\mathrm{SiO2}$ & 20.82 \\
\hline Alumina & $\mathrm{AlO3}$ & 4.34 \\
\hline Iron oxide & Fe2O3 & 4.20 \\
\hline Magnesia & $\mathrm{MgO}$ & 3.15 \\
\hline Sulfate & SO3 & 2.45 \\
\hline Loss on ignition & L.O.I & 2.33 \\
\hline Insoluble residue & I.R & 1.26 \\
\hline Lime saturation factor & L.S.F & 0.89 \\
\hline
\end{tabular}

Table (2): Physical properties of the Ordinary Portland cement used during the present investigation.

\begin{tabular}{|c|c|c|}
\hline Physical Properties & Test Results & \\
\hline Fineness $\left(\mathrm{m}^{2} / \mathrm{kg}\right)$ & 265 & $\begin{array}{c}230\left(\mathrm{~m}^{2} / \mathrm{kg}\right) \text { lower } \\
\text { limit }\end{array}$ \\
\hline Initial (min.) & 110 & Not less than 45 \\
\hline Final (min.) & 225 & Not more than 600 \\
\hline 3 days age $\left(\mathrm{N} / \mathrm{mm}^{2}\right)$ & 21.5 & Not less than 15 \\
\hline 7 days age $\left(\mathrm{N} / \mathrm{mm}^{2}\right)$ & 31.2 & Not less than 23 \\
\hline
\end{tabular}

Micro cement: Micro cement were used throughout the present investigation for repairing the damaged beams. The chemical composition and physical properties are tabulated in Tables (3) and (4).

Table (3): Chemical composition of the micro cement used during the present investigation.

\begin{tabular}{|c|c|c|}
\hline Compound composition & $\begin{array}{c}\text { Chemical } \\
\text { composition }\end{array}$ & Weight (\%) \\
\hline Magnesia & MgO & 2.1 \\
\hline Sulfate & SO3 & 2.35 \\
\hline Loss on ignition & L.O.I & 2.25 \\
\hline Insoluble residue & I.R & 0.8 \\
\hline
\end{tabular}


Table (4): Physical properties of the micro cement used during the present investigation.

\begin{tabular}{|c|c|c|}
\hline Physical Properties & Test Results & \\
\hline Fineness & 425 & \\
\hline Initial (min.) & 116 & Not less than 45 \\
\hline Final (min.) & 130 & Not more than 600 \\
\hline 3 days age (N/mm²) & 25.4 & Not less than 15 \\
\hline 7 days age (N/mm $\left.{ }^{2}\right)$ & 37 & Not less than 23 \\
\hline
\end{tabular}

Fine aggregates (sand): Fine aggregate complies with ASTM C33-01 is used in the present work for casting the reinforced concrete beams. Sieve analysis is given in Table (5).

Table (5): Sieve analysis of the fine aggregate used in the present work.

\begin{tabular}{|c|c|c|}
\hline \multicolumn{1}{|c|}{ Sieve size } & Cumulative passing \% & Limit of ASTM C33-01 \\
\hline (38-in.) $9.5-\mathrm{mm}$ & 100 & 100 \\
\hline (No. 4) $4.75-\mathrm{mm}$ & 92.96 & 95 to 100 \\
\hline (No. 8) $2.36-\mathrm{mm}$ & 84.33 & 80 to 100 \\
\hline (No. 16) $1.18-\mathrm{mm}$ & 77.89 & 50 to 85 \\
\hline (No. 30) $600-\mu \mathrm{m}$ & 59 & 25 to 60 \\
\hline (No. 50) $300-\mu \mathrm{m}$ & 19.83 & 0 to 30 \\
\hline (No. 100) $150-\mu \mathrm{m}$ & 4.25 & \\
\hline
\end{tabular}

Micro fine aggregates: Micro sand (300-75) $\mu \mathrm{m}$, complies with ASTM C33 is used for nano materials used for repairing the damaged beams.

Coarse aggregates (gravel): Coarse aggregate complies with ASTM C33-01 is used in the present work for constructing the reinforced concrete beams. Sieve analysis is given in Table (6).

Table (6): Sieve analysis of coarse aggregate used in the present work.

\begin{tabular}{|c|c|c|}
\hline Limit of ASTM c33-01 & Cumulative passing \% & Sieve size \\
\hline $25.0 \mathrm{~mm}$ & 100 & 95 to 100 \\
\hline (1/2 in.) $12.5 \mathrm{~mm}$ & 73.4 & 50 to 85 \\
\hline (No. 4) $4.75 \mathrm{~mm}$ & 3.3 & 0 to 10 \\
\hline (No. 8) $2.36 \mathrm{~mm}$ & $\mathbf{0}$ & 0 to 5 \\
\hline
\end{tabular}

Steel bars: $12 \mathrm{~mm}$ and $10 \mathrm{~mm}$ dia. bars for flexural and stirrup reinforcement of the beams. The mechanical properties of the bars used are given in Table (7).

Table (7): Mechanical properties of steel bars used in the present work.

\begin{tabular}{|c|c|c|}
\hline Dim. $(\mathrm{mm})$ & Yield strength $(\mathrm{MPa})$ & Ultimate strength $(\mathrm{MPa})$ \\
\hline$\Phi 6 \mathrm{~mm}$ & 490 & 582 \\
\hline$\Phi 10 \mathrm{~mm}$ & 543 & 712 \\
\hline$\Phi 12 \mathrm{~mm}$ & 547 & 730 \\
\hline
\end{tabular}


Steel plates: $2 \mathrm{~mm}$ steel plates used in the present work and the yield strength and ultimate strength are 528 and $588 \mathrm{MPa}$ respectively.

Wire mesh: Two types of galvanized welded square wire mesh were used in the present work. The mechanical properties of the wire mesh are given in Table (8).

Table (8): Mechanical properties of wire mesh used in the present work

\begin{tabular}{|c|c|c|c|c|}
\hline Type of reinforcement & $\begin{array}{c}\text { Opening } \\
\mathbf{m m}\end{array}$ & Diameter mm & $\begin{array}{c}\text { Yield strength } \\
\text { Mpa }\end{array}$ & $\begin{array}{c}\text { Ultimate strength } \\
\text { Mpa }\end{array}$ \\
\hline Wire mesh (1) & 12.7 & 1 & 440.7 & 488.9 \\
\hline Wire mesh (2) & 2.5 & 0.4 & 320.5 & 350 \\
\hline
\end{tabular}

Silica fume: Nano particles $(500-40 \mu \mathrm{m})$ is used Nano silica $(500-100) \mu \mathrm{m}$, the chemical and mechanical properties of nano silica fume used in the present investigation are given in Tables (9) and (10).

Table (9): Chemical composition of nano silica fume.

\begin{tabular}{|c|c|c|c|c|}
\hline \multirow{2}{*}{$\begin{array}{c}\text { Pozzolanic } \\
\text { activity }\end{array}$} & \multirow{2}{*}{$\begin{array}{c}\text { Limit of } \\
\text { ASTM } \\
\text { C1240-03 }\end{array}$} & \multicolumn{2}{|c|}{ Chemical decomposition } & \multirow{2}{*}{$\begin{array}{c}\text { Limit of } \\
\text { ASTM } \\
\text { C1240-03 }\end{array}$} \\
\hline & & Oxides & Result $\%$ & \\
\hline \multirow[t]{5}{*}{$121.5 \%$} & \multirow[t]{5}{*}{$105 \%$} & L.O.I & 3.89 & $6 \% \operatorname{Max}$ \\
\hline & & $\mathrm{SiO}_{2}$ & 91.03 & $85 \% \mathrm{Min}$ \\
\hline & & $\mathrm{Al}_{2} \mathrm{O}_{3}$ & 4.02 & - \\
\hline & & $\mathrm{Fe}_{2} \mathrm{O}_{3}$ & 0.32 & - \\
\hline & & $\mathrm{SO}_{3}$ & 0.73 & - \\
\hline
\end{tabular}

Table (10) mechanical properties of nano silica fume.

\begin{tabular}{|c|c|}
\hline Particle size & $<1$ Micro meter \\
\hline Specific gravity & 2.2 \\
\hline Surface area & $13-30 \mathrm{~m}^{2} / \mathrm{gm}$ \\
\hline
\end{tabular}

Nano metakaoline: By burning pure kaolin with $750{ }^{\circ} \mathrm{C}$ for a period of 4 hours. The mechanical and chemical properties of the developed nano metakaoline in the present work are tabulated in Tables (11) and (12).

Table (11): Mechanical properties of the developed nano metakaoline.

\begin{tabular}{|c|c|}
\hline Particle size & $<1$ Micro meter \\
\hline Specific gravity & 2.2 \\
\hline Surface area & $13-30 \mathrm{~m}^{2} / \mathrm{gm}$ \\
\hline
\end{tabular}


Table (12): Chemical composition of the developed nano clay

\begin{tabular}{|c|c|}
\hline Chemical composition & Contents \% \\
\hline Silicon dioxide, $\mathrm{SiO} 2$ & 49.87 \\
\hline Aluminum oxide, $\mathrm{Al}_{2} \mathrm{O}_{3}$ & 32.11 \\
\hline Ferric oxide, $\mathrm{Fe}_{2} \mathrm{O}_{3}$ & 8.78 \\
\hline Calcium oxide, $\mathrm{CaO}$ & 0.34 \\
\hline Titania & $1, \varepsilon \circ$ \\
\hline $\mathrm{MgO}$ & 0.28 \\
\hline $\mathrm{K}_{2} \mathrm{O}$ & 0.81 \\
\hline $\mathrm{Na}_{2} \mathrm{O}$ & 0.77 \\
\hline Loss on Ignition & 0.66 \\
\hline
\end{tabular}

Steel bolts: Steel bolts number 4.8 with size 17 are used in fixing sections for repairing the damaged part of the beams. The ultimate shear strength was found to be $17.3 \mathrm{kN}$.

Carbon fiber reinforced polymer (CFRP): Carbon fiber type (Sika Warp Hex-230c) was used in the present work for strengthening the reinforced concrete beams. Table (13) gives the physical properties of the carbon fibers ${ }^{5}$.

Table (13): Physical properties of the carbon fibers Sika Warp Hex-230c.

\begin{tabular}{|c|c|c|}
\hline 1 & Fiber type & High strength carbon fibers \\
\hline 2 & Fiber orientation & $0^{0}$ (unidirectional) \\
\hline 3 & Construction & $\begin{array}{c}\text { Warp: Carbon fibers }(99 \% \text { of total a real weight) } \\
\text { Weft: Thermoplastic heat-set fiber(1\% of total a real weight }\end{array}$ \\
\hline 4 & A real weight & $225 \mathrm{gm} / \mathrm{cm}^{2}$ \\
\hline 5 & Fiber density & $1780 \mathrm{~kg} / \mathrm{m}^{3}$ \\
\hline 6 & Fiber design thickness & $0.13 \mathrm{~mm}$ (Based on total area of carbon fiber) \\
\hline 7 & Tensile strength & $3500 \mathrm{~N} / \mathrm{mm}^{2}$ \\
\hline 8 & Tensile -E-modulus & $230,000 \mathrm{~N} / \mathrm{mm}^{2}$ \\
\hline 9 & Elongation at break & $1.5 \%$ \\
\hline 10 & Fabric length / roll & $\geq 45.7 \mathrm{~m}$ \\
\hline 11 & Fabric width & $305 / 610 \mathrm{~mm}$ \\
\hline 12 & Shelf life & Unlimited \\
\hline 13 & Package & 1 roll in card board box \\
\hline
\end{tabular}

The mechanical properties of the carbon fibers used in the present study are tabulated in Table (14).

Table (14): Mechanical properties of carbon fiber used in the present study.

\begin{tabular}{|c|c|c|}
\hline Notes & Yield strength $(\mathrm{MPa})$ & Ultimate strength $(\mathrm{MPa})$ \\
\hline Without epoxy & $\mathbf{8 0 6}$ & $\mathbf{8 4 9}$ \\
\hline With epoxy & $\mathbf{9 6 9}$ & $\mathbf{1 0 9 5}$ \\
\hline
\end{tabular}

Binder materials: Epoxy binder type (SikaDure-330) was used. The Epoxy is a medium viscosity and consists of two parts; A resin and it is white in color and $\mathrm{B}$ as hardner and it is grey in color. Mixing ratio considered in the present investigation was (1:4). The physical properties of the binder are tabulated in Table (15).

Table (15): Physical properties of the epoxy binder used in the present work.

\begin{tabular}{|c|c|}
\hline Density & $1.31 \mathrm{Kg} / \mathrm{L} \mathrm{mixed} \mathrm{(Comp.} \mathrm{A+B)}$ \\
\hline Mixing ratio (A:B) by weight & $\begin{array}{c}1: 4 \\
+15^{\circ} \mathrm{C}: 90 \mathrm{~min} . \\
+35^{\circ} \mathrm{C}: 35 \mathrm{~min} .\end{array}$ \\
\hline Pot life & $+35^{\circ} \mathrm{C}: 30 \mathrm{~min}$. \\
\hline Open time & $\begin{array}{c}\text { Pasty, not flow able. } \\
\text { Viscosity }\end{array}$ \\
\hline Application temperature & $\begin{array}{c}\text { Substrate and ambient temperature: } \\
+15^{\circ} \mathrm{C} \text { to }+35^{\circ} \mathrm{C}\end{array}$ \\
\hline Adhesive tensile strength on concrete & $\begin{array}{c}\text { Concrete fracture after } 1 \text { day }\left(>15^{\circ} \mathrm{C}\right), \text { on sandblasted } \\
\text { substrate }\end{array}$ \\
\hline Tensile strength & $\left(\right.$ Curing 7 day, $\left.+23^{\circ} \mathrm{C}\right)=30 \mathrm{~N} / \mathrm{mm}^{2}$ \\
\hline Flexural-E-Modulus & $\left(\right.$ Curing 7 day, $\left.+23^{\circ} \mathrm{C}\right)=3800 \mathrm{~N} / \mathrm{mm}^{2}$ \\
\hline
\end{tabular}

Fumed silica: The properties of nano fumed silica are given in Table (16). 
Table (16) Properties of fumed silica used during the injection of the cracks.

\begin{tabular}{|c|c|}
\hline Parameter & Specification \\
\hline Specific surface, $\mathrm{m} 2 / \mathrm{gr}$ & $\mathbf{2 0 0 , ( 1 6 0 - 2 4 0 )}$ \\
\hline Ph-value & $3.7-4.7$ \\
\hline Loss on drying, $\%$ & 3 \\
\hline
\end{tabular}

Super plasticizers: The super plasticizer used is Sikament®FFN and complies with ASTM C494. The specifications are given in Table (17).

Table (17): Specifications of the super plasticizer used in the present work.

\begin{tabular}{|c|c|}
\hline Main Action & Concrete Super plasticizer \\
\hline Form & Viscous Liquid \\
\hline Color & Brown homogenous liquid \\
\hline Relative Density & $1.20-1.24 \mathrm{~kg} / \mathbf{l}$, at $20^{\circ} \mathrm{C}$ \\
\hline pH value & 6.42 \\
\hline Freezing point & $-5^{\circ} \mathrm{C}$ \\
\hline Total Chloride Ion Content & Max. $0.1 \%$, Chloride-free \\
\hline $\begin{array}{c}\text { Equivalent Sodium Oxide as } \% \\
\text { Na2O }\end{array}$ & Max. $\% 7$ \\
\hline
\end{tabular}

Water: Tap water was used in mixing and curing all concrete and cement mortar mixture considered in this study.

\section{Mixing design and procedure}

All tested beams were cast with mixing ratio of cement/ fine aggregate/ coarse aggregate 1:1.5:3 respectively by weight with water/ cement ratio of 0.4 . It was designed to achieve a concrete cube compressive strength of $32 \mathrm{~N} / \mathrm{mm}^{2}$ at 28 curing days according to B.S. 116:1989. The mixing of concrete was carried out in a rotary pan type mixer of $0.1 \mathrm{~m}^{3}$ capacity. In all mixes of concrete, the aggregate and cement were first mixed dry for about 60 seconds and for further 120 seconds after the addition of water. Steel moulds with inner dimensions 150x200x2200 mm as shown in photo (1) were prepared for casting all the beams.

After the steel moulds were cleaned and lightly oiled, the previously prepared steel reinforcement was placed inside the mould and justifies the concrete cover by multi spacers. Then the concrete was poured and vibrated, the top surface was then smoothed and covered with polythene sheets. After 24 hours the mould and control specimens were demolded and cured for 28 days. With each beam three $150 \mathrm{~mm}$ cubes for compressive strength $(f c u)$ were cast to determine the compressive strength of the hardened concrete.

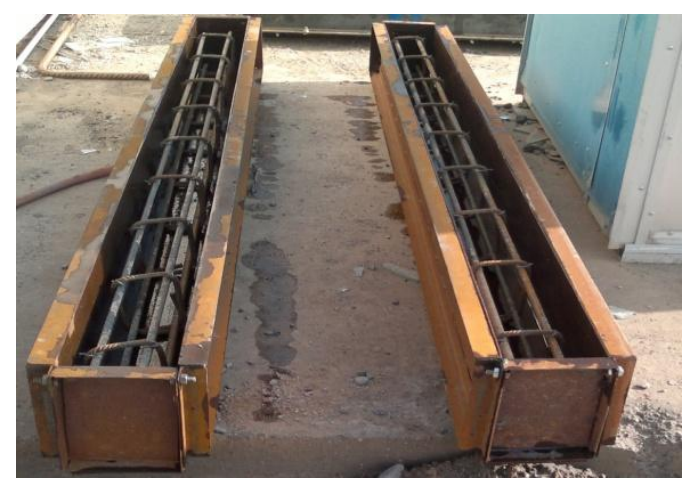

Photo (1) Steel moulds for casting the all reinforced concrete beams. 


\section{Testing program}

The beams were tested up to failure load in a Universal Testing Machine under point loading at midspan. As it was mentioned earlier, all beams were design for flexural failure, in which 4-12 mm diam. bars (2bars at the top and 2-bars at the bottom) as the reinforcement with $10 \mathrm{~mm}$ bar dia. At $250 \mathrm{~mm}$ c/c as stirrups were considered as shown in the Figure (2) and Photo (2).
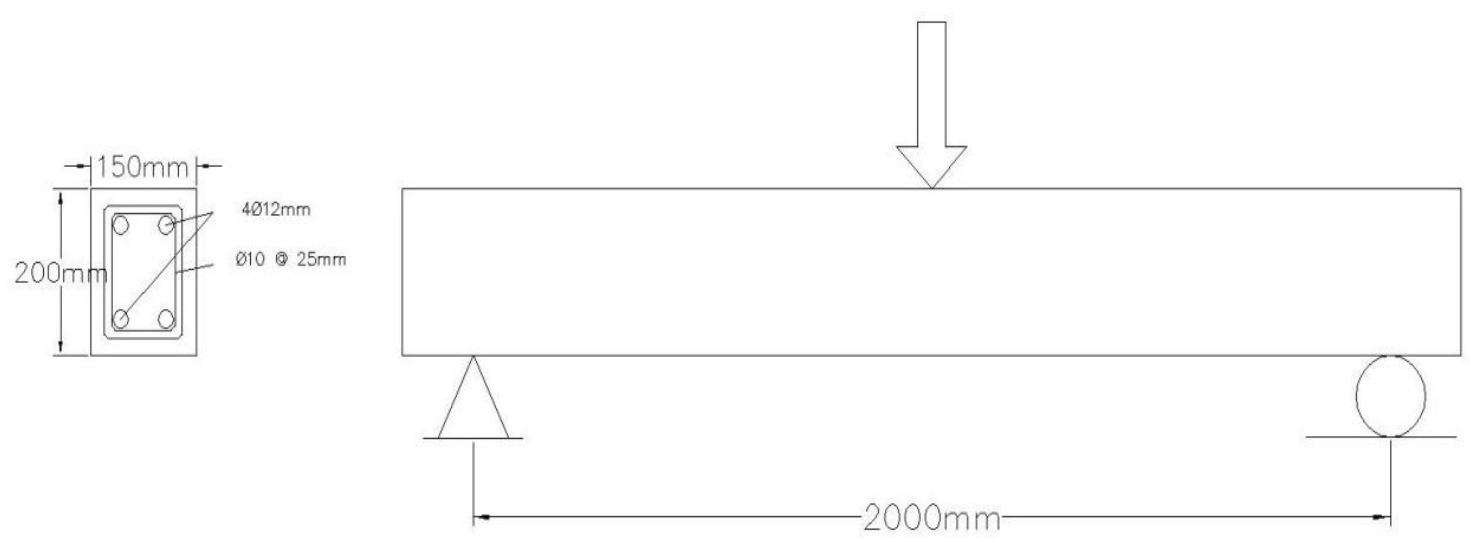

Figure (2) Dimensions and detailing reinforcement of the beams considered in the present investigation.

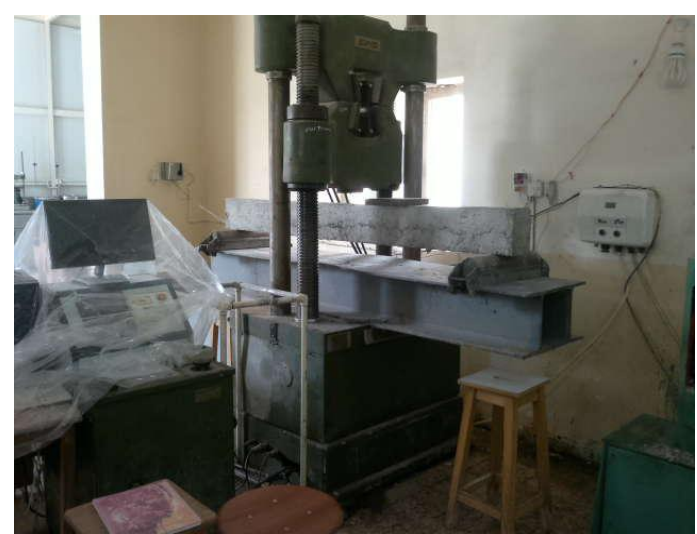

Photo (2) Beam under the test.

\section{Techniques used for repairing:}

The collapsed beams removed from the testing machine and loose debris were first removed. Then water was sprinkled on the crushed part of the beams to remove the loss particles. Then cement mortar with ratio of $1: 1$ as cement/ sand passing sieve $2.36 \mathrm{~mm}$ is used with water/ cement ratio $=0.4$ for plastering the crushed parts of the tested beams as shown in photo (3).

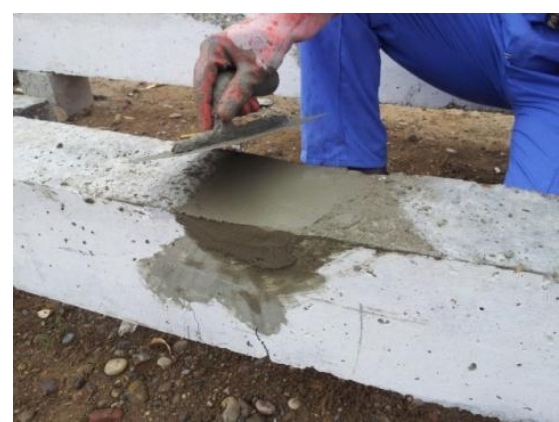

Photo (3) View of the crushed part of the beam after flexural testing. 
The 12 preloaded the damaged reinforced concrete beams were rehabilited as follows:

(a) Rehabilitation of the damaged part of the tested beam using ferrocement composite technique. Three $\mathrm{U}$ ferrocement cross section as shown in Fig. (4) were cast with length of $700 \mathrm{~mm}$ and mixing ratio of the cement mortar (cement: sand $=1: 1$ ) and water :cement ratio $=0.4$ prior to fixing the sections to the damaged part of the beams. Fig. (5) and photo (4) show the methods of fixing the elements.

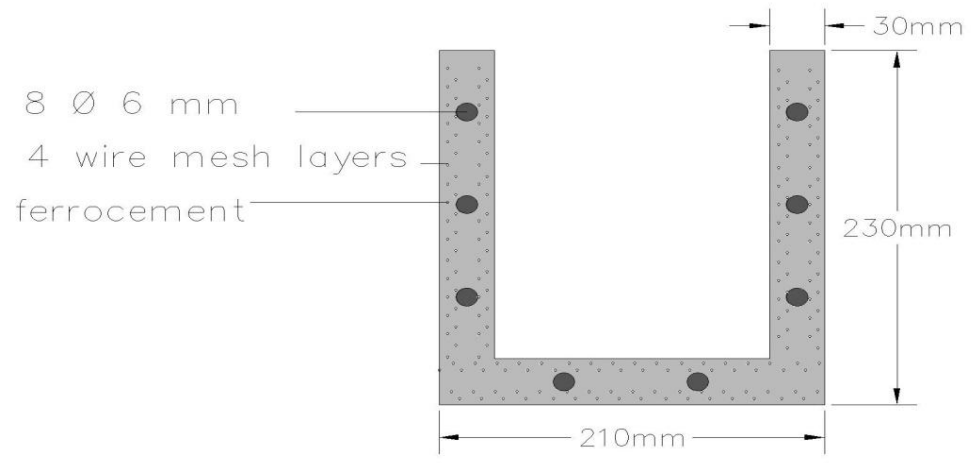

Fig. (4) Details of ferrocement cross section.
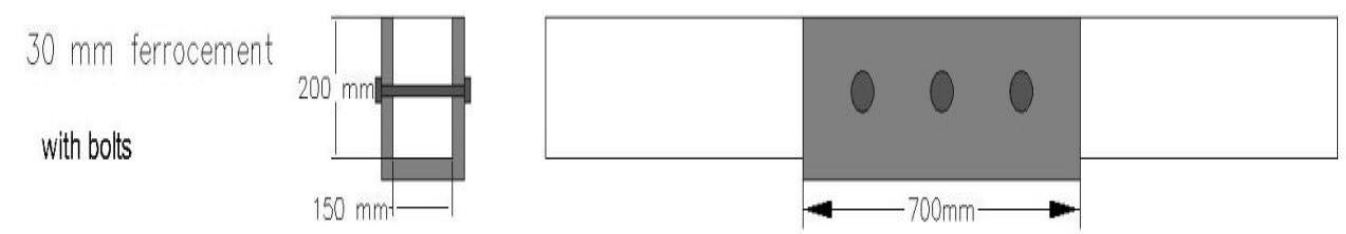

$30 \mathrm{~mm}$

ferrocement with

epoxy
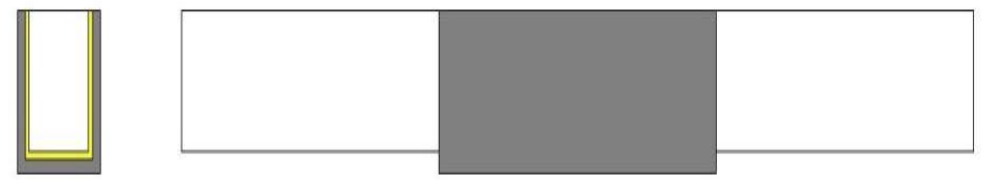

$30 \mathrm{~mm}$ ferrocement with epoxy and bolts
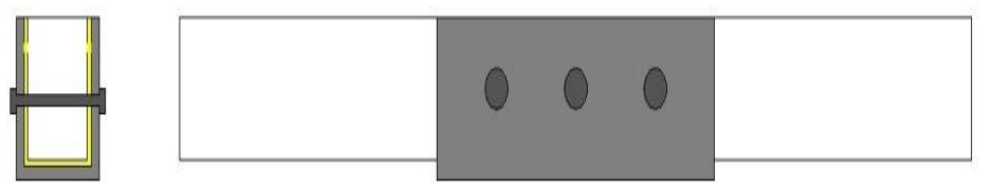

Fig. (5) Methods of fixing U ferrocement element. 

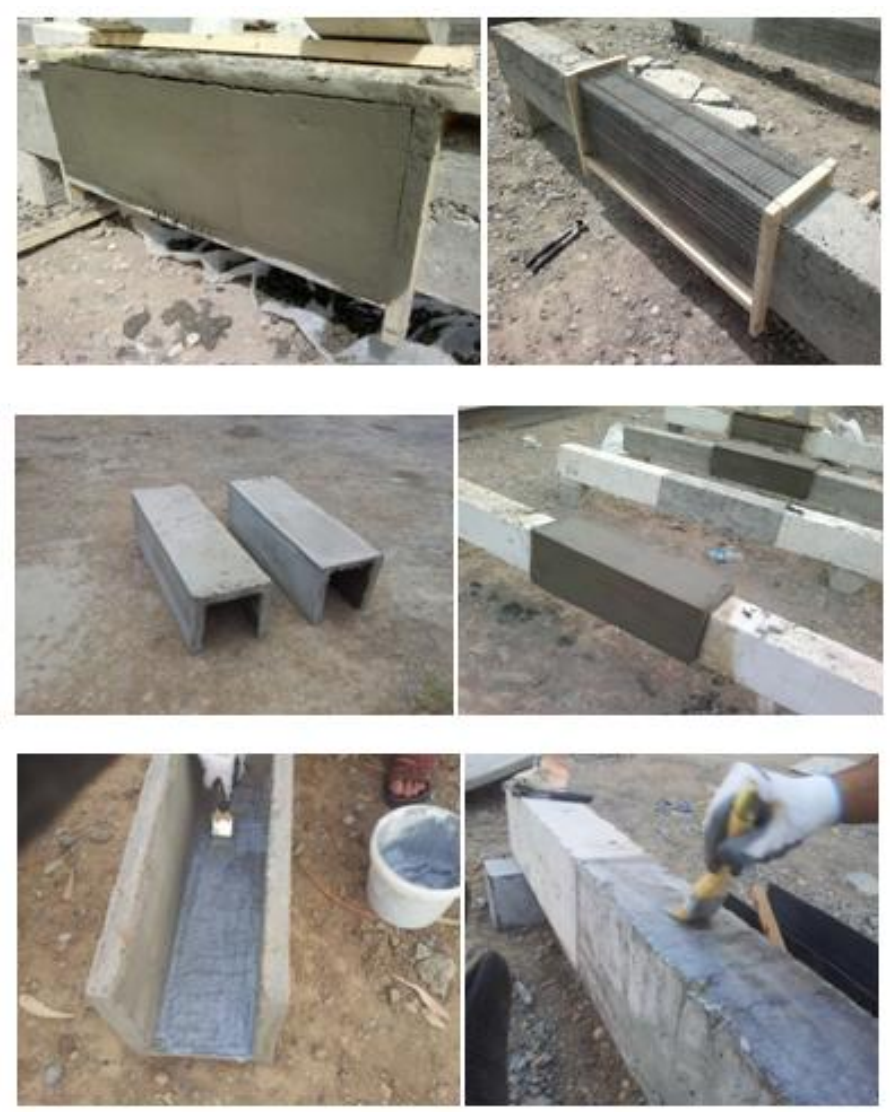

Photo (4) Methods of casting and fixing the ferrocement sections.

(b) Rehabilitation of the damaged part of the tested beams using steel section technique. Fig. (6) shows the methods of fixing the elements.
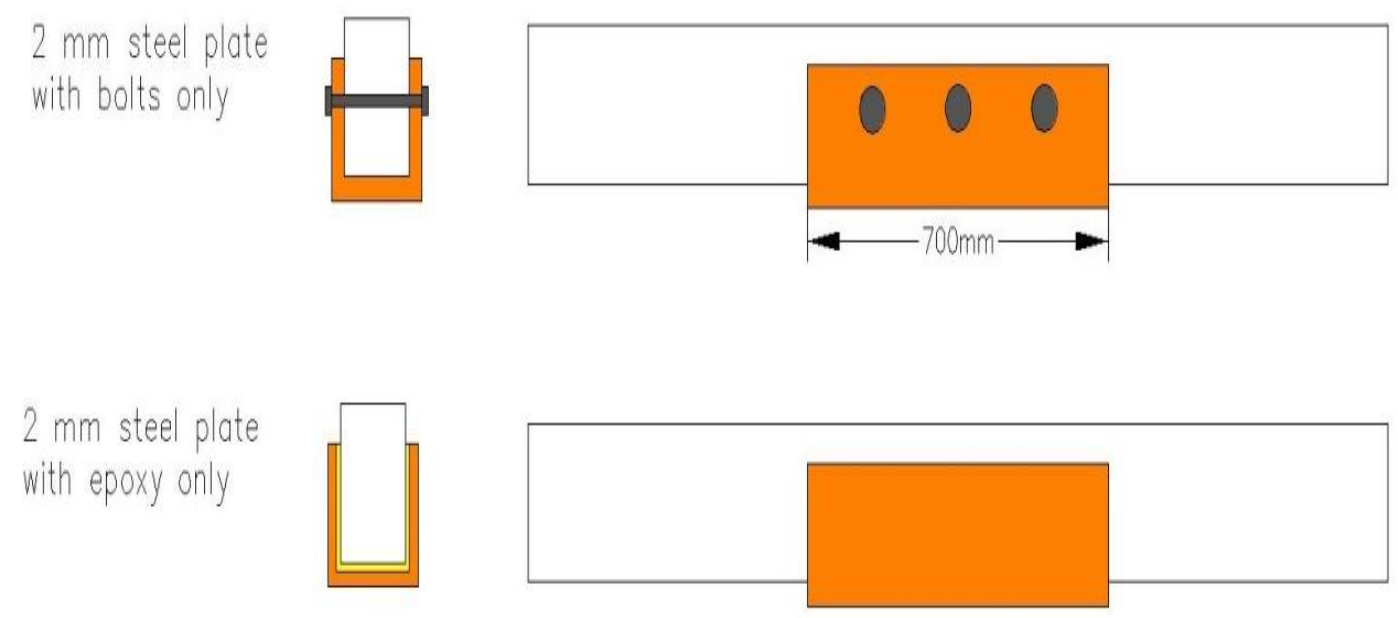

2 mm steel

plate with epoxy and bolts
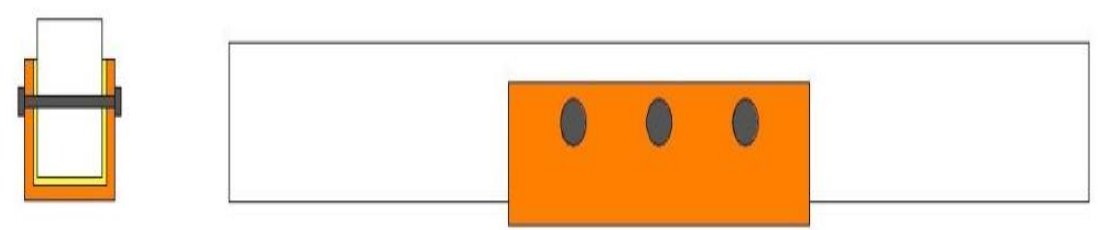

Fig. (6) Methods of fixing steel element. 
(c) Rehabilitation of the damaged part of the tested beams using carbon fiber technique. Fig. (7) and photo (5) show the methods of fixing the element.

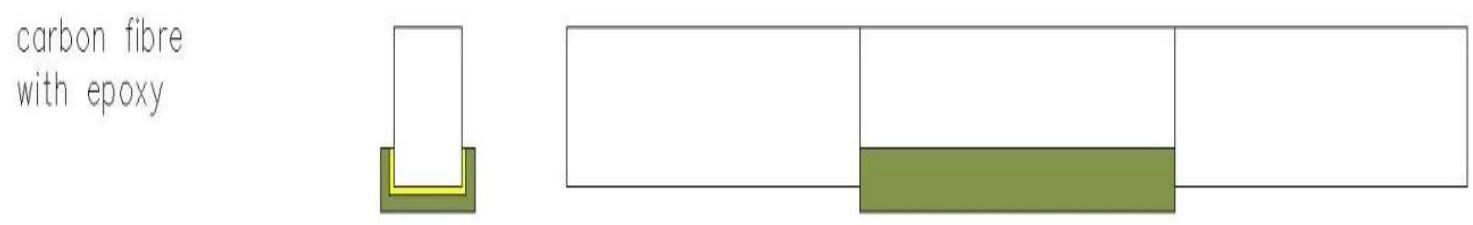

Fig. (7) Method of fixing carbon fiber layers.

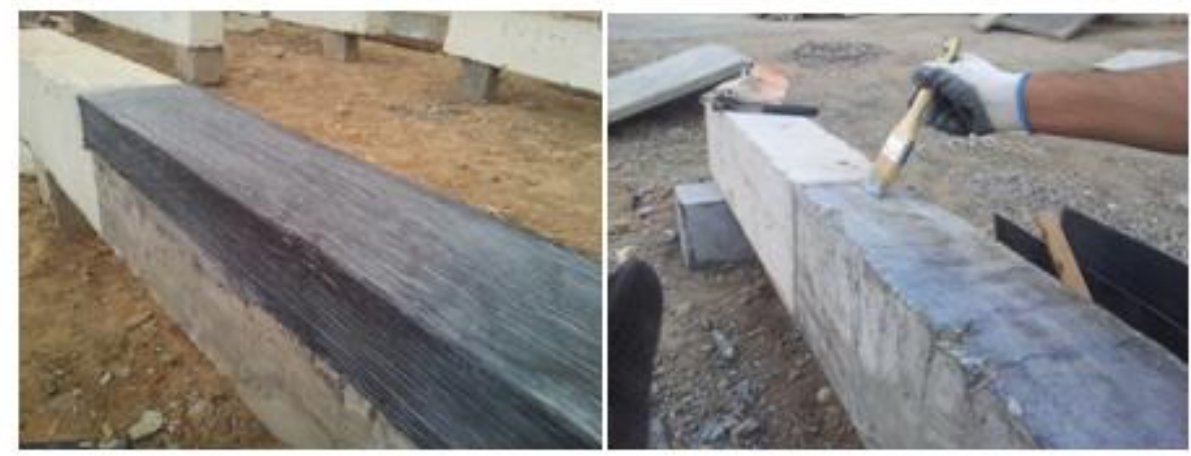

Photo (5) Method of rehabilitate the damaged beam using carbon fiber.

(d) Rehabilitation of the damaged part of the tested beam by U section cast by the developed nano ferrocement, see Fig. (8) and photo (6).
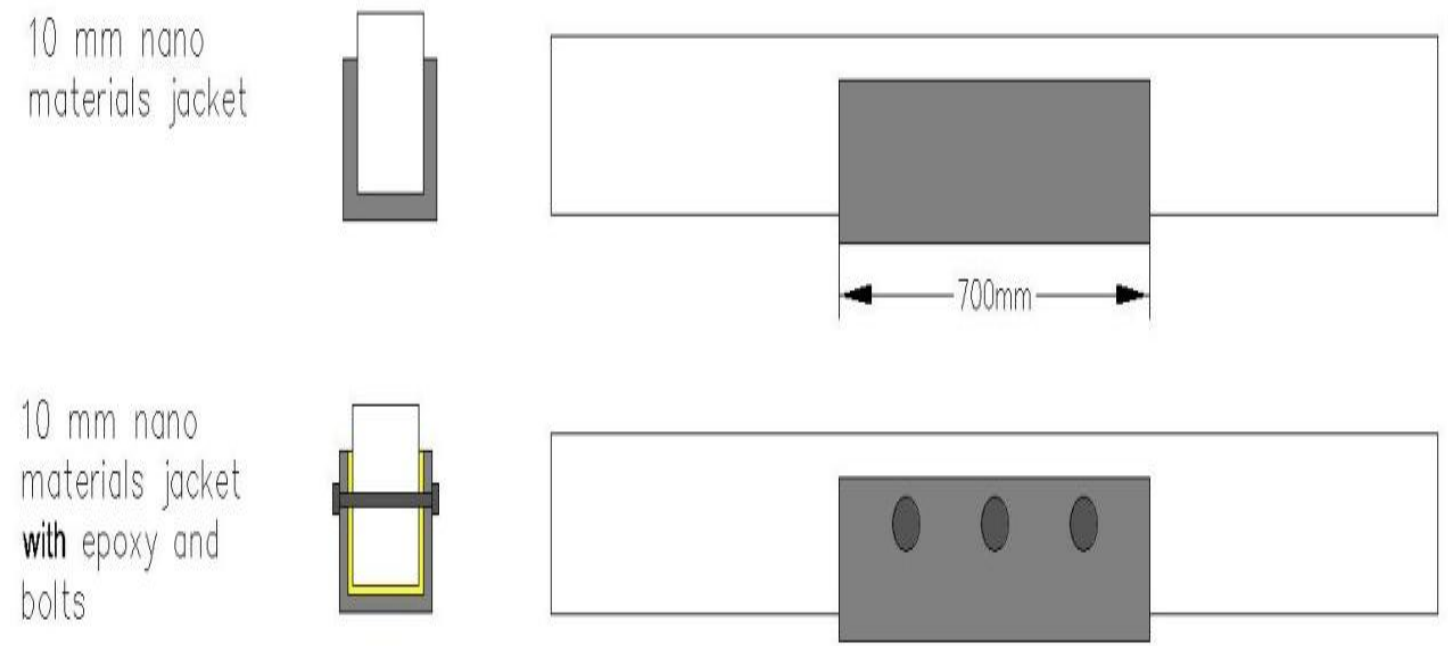

Fig. (8) methods of fixing sections made from the developed nano ferrocement. 

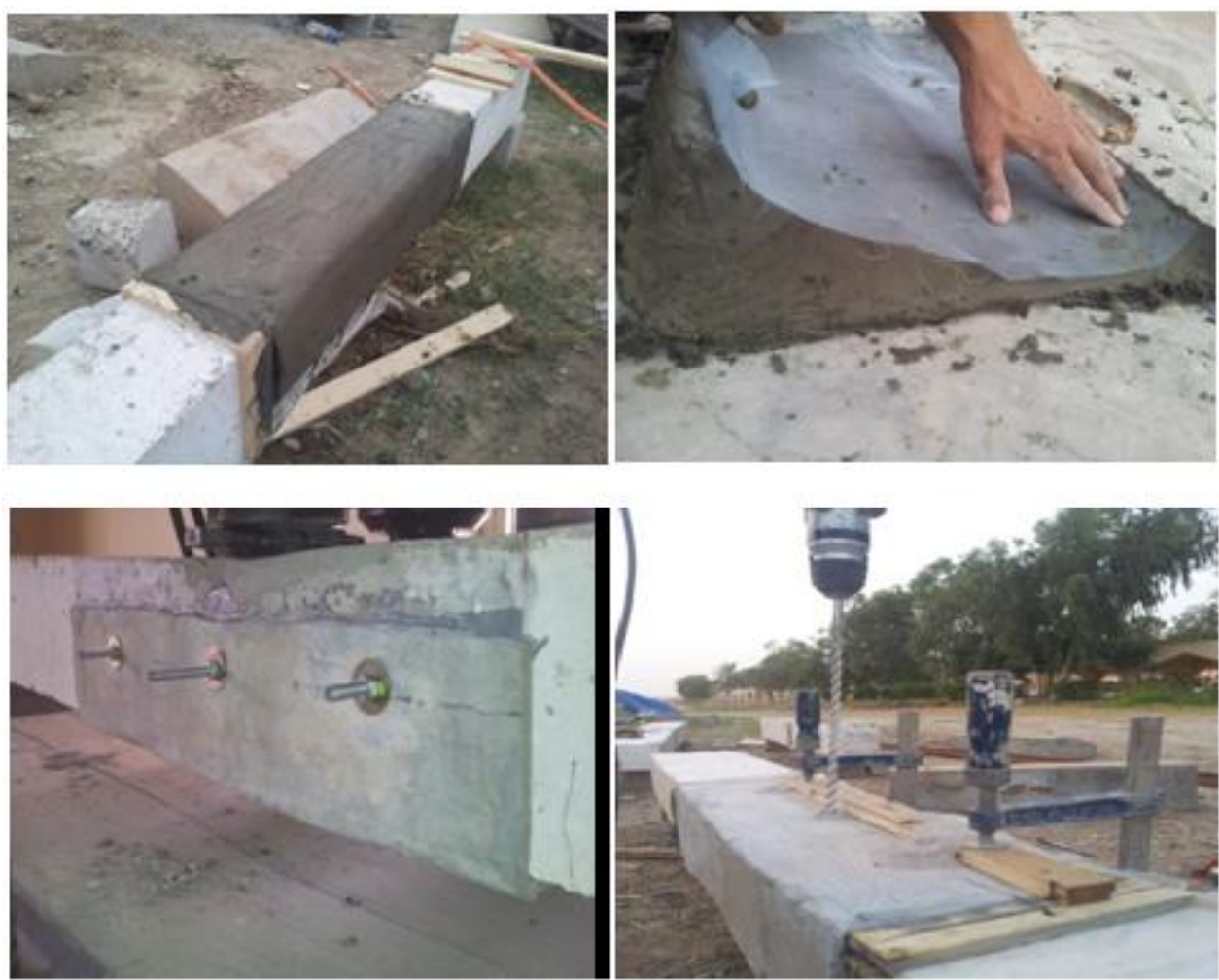

Photo (6) Casting and fixing the developed nano ferrocement section.

(e) Rehabilitation of the damaged part of the tested beams using injection technique by nano materials.

Cracks of the damaged beam were injected as shown in photo (7), by the following mixture.

1. $60 \%$ of micro cement.

2. $40 \%$ of nano fumed silica.

3. Super plasticizers ( $2 \% \mathrm{x}$ weight of cement).

4. $\mathrm{w} / \mathrm{c}$ ratio $=0.4$.

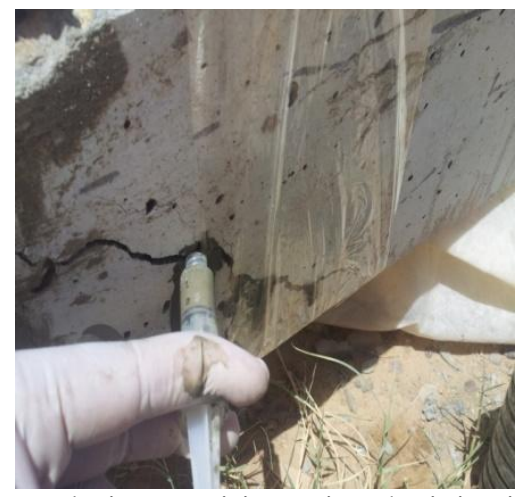

Photo (7) Beam during repairing using the injection technique.

Instrumentations:

1. Ultimate loads were measured using Universal Testing Machine with a capacity of $1000 \mathrm{kN}$.

2. Compressive strength of concrete cubes was tested using compression machine Wekob.

3. Ultra-sonic, type (V-Meter MK IV) to measure the compressive strength of the tested beams.

\section{Test results and discussions:}

The test results are summarized in Table (18). It shows the comparative representation of all the twelve beams distressed by ultimate load $\mathrm{Pu}$ and rehabilitated. 
1. The technique of using bolts in fixing the new elements for rehabilitation of the damaged part of the loaded beams showing excellent results, in which the ratios of ultimate load after rehabilitation/ actual ultimate load of ferrocement and steel jackets are $105 \%$ and $100.8 \%$ respectively.

2. It may be seen that using epoxy for fixing the ferrocement or steel section for rehabilitation is less efficient than using epoxy for fixing carbon polymer fibers, in which the ratios of original ultimate load/ultimate load after rehabilitation are $87 \%$ and $87.4 \%$ using epoxy for fixing ferrocement and steel sections respectively. While ratio reach $100 \%$ when using epoxy for fixing carbon polymer fibers.

3. But, the ratio reaches $100 \%$ of the original beams using ferrocement or steel jacket when using epoxy and bolts together.

4. The ultimate load of beam after rehabilitation is $99 \%$ of the original ultimate load when using nano ferrocement jacket for rehabilitation.

5. Using nano materials injection technique tend to reach the ultimate load for beam after rehabilitation to $80 \%$ of the original loads. But this technique was tested for tested span of $2 \mathrm{~m}$. Further study need to be conducted for further spans.

6. It may be noted that Ultra-Sonic tests were carried out to measure the value of compression strength of concrete before flexural testing to failure and after repairing using injection technique by the developed nano/ micro materials. It was found that concrete was recovered its compressive strength after repairing by about $61 \%$.

During uploading the pre-damaged rehabilitated beams, it was observed that cracks were occurred and number of cracks were increased by increasing the loads even in the injected cracks and the first flexural cracking strength were recorded as $62.99,57.27$, and $50 \%$ of the first cracking strength before rehabilitation respectively. Also, the ultimate flexural strengths were recorded as $85.87,85.09$, and $82.77 \%$ in comparison with ultimate flexural strength before rehabilitations respectively.

Table (18): The measured values of first crack and ultimate loads of the tested beams with nano cement mortar injection for rehabilitation.

\begin{tabular}{|c|c|c|c|c|c|c|c|}
\hline & \multirow{2}{*}{ Method of rehabilitation } & \multicolumn{2}{|c|}{$\begin{array}{l}\text { Compressive strength of } \\
\text { concrete, } f c u ., M P a\end{array}$} & \multirow{2}{*}{$\begin{array}{l}\text { First cracking load } \\
\qquad(F c r, \\
k N)\end{array}$} & \multirow{2}{*}{$\begin{array}{l}\text { First cracking } \\
\text { load }(F c r ., \\
k N) \text { after } \\
\text { repairing. }\end{array}$} & \multirow[t]{2}{*}{$\begin{array}{l}\text { Ultimate load } \\
(\text { Fult., } k N)\end{array}$} & \multirow{2}{*}{$\begin{array}{l}\text { Ultimate load } \\
(F u l t ., k N) \text { after } \\
\text { repairing. }\end{array}$} \\
\hline & & Concrete & $\begin{array}{c}\text { Cement } \\
\text { mortar/ or } \\
\text { nano } \\
\text { materials }\end{array}$ & & & & \\
\hline \multirow[b]{3}{*}{ a } & U-Ferr. sec. with bolts & 30 & 33.87 & 12.7 & 13 & 42.7 & 45.1 \\
\hline & U-Ferr. sec. with epoxy & 33 & 32.9 & 14 & 11.5 & 45.6 & 39.7 \\
\hline & $\begin{array}{l}\text { U-Ferr. sec. with bolts and } \\
\text { epoxy }\end{array}$ & 34 & 33.9 & 13 & 12.5 & 50 & 54 \\
\hline \multirow[b]{3}{*}{$\mathrm{b}$} & U-Steel sec. with bolts & 35 & - & 11 & 10 & 47.1 & 47.5 \\
\hline & U-Steel sec. with epoxy & 35.6 & - & 12 & 9.8 & 50 & 43.7 \\
\hline & $\begin{array}{l}\text { U-Steel sec. with bolts and } \\
\text { epoxy }\end{array}$ & 31.5 & - & 15.6 & 16 & 51 & 51 \\
\hline $\mathrm{c}$ & Carbon fiber & 35.4 & - & 13.7 & 11 & 47.6 & 48 \\
\hline \multirow[t]{2}{*}{ d } & $\begin{array}{l}\text { U-Nano } \\
\text { materials. }\end{array}$ & 36 & 36.6 & 13 & 14.7 & 50.5 & 50 \\
\hline & $\begin{array}{l}\text { U-Nano materials. with bolts } \\
\text { and epoxy }\end{array}$ & 36.2 & 37.2 & 11 & 10 & 52 & 53.5 \\
\hline \multirow{3}{*}{$\mathrm{e}$} & \multirow{3}{*}{ Injection by nano materials } & - & 33.1 & 12.7 & 8 & 44.6 & 38.3 \\
\hline & & - & 35 & 11 & 6.3 & 53 & 45.1 \\
\hline & & - & 29 & 13 & 6.5 & 56.9 & 47.1 \\
\hline
\end{tabular}

\section{Conclusions}

Using different techniques for rehabilitation of the damaged beams in buildings are illustrated in the present investigation.

\section{References}

[1]. Ye, L., Yue, Q., Zhao, S., and Li, Q.,2002, "Shear Strength of Reinforced Concrete Columns Strengthened with Carbon-FiberReinforced Plastic Sheet ", journal of structural engineering, Vol. 128 , No. 12, pp. 127-134.

[2]. H. Hsing, H. Tsong, Y. Hwei and Yiching L., 2005, "Strengthening reinforced concrete beams using pre-stress glass fiber reinforced polymer - part II: Excremental study ", journal of zhejian university SCIENCE ,p. 844-852.

[3]. Teng, J.G., Lam, L., Chan, W., and Wang, J., 2000,"Retrofitting of Deficient RC Cantilever slab using GFRP strips ", Journal of composite for construction, Vol. 4, No. 2, May, pp.75-84.

[4]. Lamanna, A.J.,2002, "Flexural Strengthening of Reinforced Concrete Beams with Mechanically Fastened Fiber Reinforced Polymer Strips", Ph.D. Thesis, University of Wisconsin-Madison, pp287. 
[5]. Van Gemert, D. and Maess Chalk, R., 1983, "Structural Repair of a Reinforced Concrete Plate by Epoxy Bounded External Reinforcement", the International Journal of Cement Composites and Lightweight Concrete, Vol. 5, No. 4, Nov. pp. $247-255$.

[6]. Mays, and Calder, 1989, "External Plates extend reinforcement reach", Concrete Journal. Vol 23, No. 1. ACI Publication SP.61, 1979,"Ferrocement-Materials and application", pp 1-195.

[7]. Subrahmanyam, B.V., et.al., 1979, "Ferrocement Technology: a Critical Evaluation, The International Journal of Cement Composites" Volume 1, Number 3, October, pp 125-139.

[8]. Parmansivam, p., 1988, “Ferrocement Structure and Structural Elements", Elsevire Applied Science, London, pp $289-338$.

[9]. ACI Committee 549, 1988 "State - of - the - Art Report on Ferrocement", ACI Manual of Concrete Practice, part 5.

[10]. Hossain, M. , et.al., 1992 , "Behavior of Reinforced Concrete Ferrocement Composites", Fiber Reinforced Cement Edited by R.N. Swamy, Rilem published by E \& FN Spon, 2.6 Bonday Row, London SEI 8 HN.

[11]. Rosenthal and F.Bljuger, 1985, "Bending behavior of ferrocement-reinforced concrete composite" Journal of Ferrocement, Vol. 1, Jan., pp 15-24.

[12]. Hossain, M. , et.al., 1992 , "Behavior of Reinforced Concrete Ferrocement Composites", Fiber Reinforced Cement Edited by R.N. Swamy, Rilem published by E \& FN Spon, 2.6 Bonday Row, London SEI 8 HN.

[13]. Abdul-Ameer O. A.,2000, “ Ability of ferrocement to raise the resistance of reinforced concrete beams subjected to impact load", M.SC. theses, University of Technology.

[14]. S. P. Shang, L. O. Zeng , H. Peng , 2003 , "Flexural strengthening of reinforced concrete beam with ferrocement" , 28th Conference on OUR WORLD IN CONCRETE \& STRUCTURES , Hunan University, China.

[15]. Sivagurunathan, vidivelli ,2011, ““'Concrete beams strengthened by ferrocement ”emerging journal on engineering science and technology pp( 1-5) volume (5) issue no . 1.

[16]. Sivagurunathan. Ba ., and Vidivelli. Bb, 2012 , "Strengthening of Predamaged Reinforced Concrete Beams by Ferrocement Plates", International Journal of Current Engineering and Technology, Vol.2, No.4(Dec. 2012).

[17]. Jones, R., Swamy , 1980 , "Composite Behavior of Concrete Beams with Epoxy Bounded External Reinforcement", The International Journal of Cement Composites, Vol.2, No. 2 .

[18]. Mukhopadhyaya, Ph., Swamy, N. and Lynsdale, C., "Optimizing Structural response of beams strengthening with GFRP plates", Journal of Composites for Construction, Vol. 2, No. 2, May 1998, pp.87-95.

[19]. Arshed .A.A ,2012,., "Repair of damaged RC. Beams with large rectangular web opening using cfrp and steel plates ",M.SC. Theses, University Tenage National.

[20]. Al-Hassani . H.M., S. A. Al-Ta'an, A. A. Mohammed, 2013, "Behavior of Damaged Reinforced Concrete Beams Strengthened with Externally Bonded Steel Plate" Tikrit Journal of Engineering sciences /Vol.20/No.2/(48-59).

[21]. Mohamed, R. A. S., Aboelezz A. Y., Sadekk A. B. , Kalafallah M. A., 2013 , " Flexure behavior of R.C. beams strengthened with different method" Minia Journal of Engineering and Technology, Minia University, Egypt, (MJET) Vol. 32, No 1.

[22]. Alagusundaramoorthy, p., Harik, I.E. and Choo, C.C., 2002, "Flexural Behavior of R/C Beams Strengthened with CFRP Sheets or Fabric", Research Report KTC-02-13/SPR 200-99-1F, University of Kentucky, College of Engineering, August, pp. 1-35.

[23]. Buyukozturk, O., and Hearing, B., 2004, "Failure behavior of Pre cracked concrete beams retrofitted with FRP", Journal of Composites for Construction, Vol. 13.No. 4, pp. 138-144.

[24]. Magureanu, C., Heghes, B. and Chiorean, A.,2007, "Strengthening with Carbon Fibers-Experimental Study", FRPRCS-8, University of Patras, Greece, Vol. 3, No. 13, pp.1-6.

[25]. Dawlat, D. A., 2007 "Experimental and Theoretical Investigation of the Behavior of Reinforced Concrete Beams Strengthened by Fiber Reinforced Polymer", Ph. D. Thesis, University of Baghdad/College of Engineering .

[26]. Gamino A.L. , and Bittencourt T.N., 2007, "Reinforced concrete beams strengthened with CFRP : excremental analytical and numerical approaches ", university of patras, Greece, vol. 3, No, 2., pp1-9.

[27]. ASTM C 33 - 01, "Standard Specification for Concrete Aggregates".

[28]. "Structural Strengthening with Sika Wrap Fabric System", Sika, pp.333, www.Sikaneareast.com.

[29]. "Structural Strengthening with Sika Wrap Fabric System", Sika, pp.332, www.Sikaneareast.com.

[30]. Leon H. Prentice, Martin J. Tyas*, Michael F. Burrow,2006, " Proceedings of The effect of ytterbium fluoride and barium sulphate nanoparticles on the reactivity and strength of aglass-ionomer cement" Proceedings of the dental materials 22 p. 746-751.

[31]. M.S. Morsy, S.H. Alsayed, M. Aqel “ Proceedings of Hybrid effect of carbon nanotube and nano-clay on physico-mechanical properties of cement mortar" Proceedings Construction and Building Materials 25 (2011) 145-149

[32]. ASTM C494/C494M " Standard Specification for Chemical Admixtures for Concrete1", Annual Book of ASTM Standards, Vol. 04.02, 2004; pp. 1-8.

[33]. British Standard Institution, B.S 1881: Part108: 1983, "Method For Making Test Cubes From Fresh Concrete".

[34]. British Standard Institution, B.S 1881: Part116: 1983, "Method for Determining of Compressive Strength of Concrete Cubes".

[35]. "Structural Strengthening with Sika Wrap Fabric System", Sika, pp.415, www.Sika.com.

[36]. Bhikshma, M. Koti Reddy and K. Sunitha. "Experimental study on rehabilitation of reinforced concrete beams using epoxy resins". Asian Journal of Civil Engineering (Building and Housing) Vol. 11. No. 4 (2011).

[37]. Sivagurunathan B. and Vidivelli B. "Strengthening of predamaged reinforced concrete beams by ferrocement plates". International Journal of Current Engineering and Technology, 2012 Inpressco. 